\title{
A POLGÁRMESTER, A FALU MEG A KÖZÖSSÉG: HOZZÁSZÓLÁS A „FÜGGETLEN” POLGÁRMESTER VITÁHOZ ${ }^{1}$
}

\author{
(The Mayor, the Village and the Community: Contribution to \\ the Debate about the „Independent" Mayor)
}

\section{BORBOLY ISTVÁN - CSITE ANDRÁS}

\section{Problémafelvetés}

Az 1990-es és az 1994-es önkormányzati választások során a megválasztott községi polgármesterek kétharmada pártoktól „függetlenül” indulva nyerte el mandátumát. A politikai pártok alacsony falusi szervezettségének (ami alól a Magyar Szocialista Párt és a Független Kisgazda- Földmunkás és Polgári Párt tekinthető talán csak kivételnek) többféle magyarázata is van. Sokan azzal érvelnek, hogy a hazai pártok csak a rendszerváltás időszakában jöttek létre, új képződmények, és így nem telt még el elég idő stabil káderállomány megszervezésére és kinevelésére. Mások arra hívták fel a figyelmet, hogy a parlamenti politikai pártok elitje különbözỏ értelmiségi elitfrakciókból jött létre, s ezek a Budapesten megszerveződőtt kapcsolathálózatok nem terjednek ki a vidéki Magyarországra.

Mind az 1994-es, mind pedig az 1998-as választásokon párttámogatottságú függetlenként, avagy pártszínekben számos (elsỏsorban városi) önkormányzati politikus is indult, ami arra utal, hogy a települési önkormányzati mezőben tevékenykedő politikusok a politikai pártok számára rekrutációs bázist jelentenek.

A települési önkormányzati politizálás jelentőségére, illetve a falusi önkormányzati politikusok társadalommobilizáló szerepére 1997-98 során két jelentős médiapublicitást kapott eseménysor is felhívta a figyelmet. Az 1997 elsó felében kibontakozó gazdatüntetések, illetve az év végén kiéleződőtt falusi etnikai konfliktusok kapcsán nyilvánvalóvá vált, hogy a helyi politikai hatalomba került polgármesterek és ơnkormányzati képviselők egy része a ,,kőzponti” kormányzati tơrekvésekkel szemben tiltakozó mozgalmak megszervezésére is képes politikai vállalkozóként lép fel.

A helyi politikusok megváltozott aktivitására utaló jelek alapján a társadalomkutatók egy része azt fogalmazta meg, hogy 1997 döntỏ változást hozott a magyar vidéki társadalom rendszerváltás utáni történetében: lezárult a tulajdonosi struktúra átalakítása. A ,kapuk záródása” koncepció szerint 1997-re nyilvánvalóvá vált, hogy a falusi társadalom tagjainak tơbbsége nem jutott üzleti tulajdonhoz, s a városi társadalmi problémák importálása révén a települések versenyében a községek döntő része előnytelen pozíciókkal bir. A helyben kezelhetetlenné váló társadalmi problémák (szegénység, búnözés, etnikai feszültségek stb.) a falusi politikai elit társa- 
Borboly István - Csite András : A polgármester, a falu meg a közösség :

Hozzászólás a „független" polgármester vitához

Tér és Társadalom 13. évf. 1999/1-2. 109-128. p.

dalommobilizáló tevékenységének eredményeként válnak helyi és országos tiltakozó mozgalmak alapjává.

Kutatási programunk indításakor (1997) azt a vizsgálati kérdést fogalmaztuk meg, hogy miként néz ki a falusi társadalom, a falusi politizálás a községi polgármesterek érvelésében. Adatgyüjtésünk eredményeként választ reméltünk arra a kérdésre is, hogy a polgármesterek milyen érvelési stratégiákat alkalmaznak a községi lakosság mobilizációja során, mely stratégiák révén a helyi tiltakozó akciók diszkurzív keretei létrejöhetnek.

Tanulmányunk első részében a helyi politika, a helyi politizálás sajátosságait, a pártoktól „független” polgármesterek problémakörét vizsgáló hazai kutatások eredményeit mutatjuk be. Ezt követően röviden kitérünk Bourdieu nyelvszociológiájának ismertetésére, mely fogalomkészletével, meglátásaival vizsgálódásaink során orientált bennünket. Tanulmányunk harmadik részében 31 falusi polgármesterrel készített interjú elemzése olvasható. Itt arra összpontositunk, hogy feltárjuk azt az értelmezési keretet, melyben a falusi politizálás tematizálódik. Végezetül felvetünk néhány olyan kérdést, melyek elemzése tovább bővítheti a falu és a vidék konstruálásáról való tudásunkat.

\section{A kilencvenes évek helyi önkormányzati kutatásai Magyarországon}

A falusi politizálás elemzésével foglalkozó kutatók számára talán a legnagyobb intellektuális kihívást az önkormányzati választások eredményeinek magyarázata jelentette. 1990-ben és 1994-ben is a falusi önkormányzati vezetők és képviselök túlnyomó többsége függetlenként jutott mandátumhoz, azaz a parlamenti demokrácia politikai rendszerének fontos szereplöi, a politikai pártok alig-alig jelentek meg a falusi önkormányzati választásokon. A komoly kutatási programokat indukáló kérdés igy magától értetődő volt: ha nem pártelven, akkor milyen elvek mentén történik a falusi önkormányzati képviselök választása.

A települési, önkormányzati vezetökröl készült írások egy része a polgármesterek társadalom-statisztikai jellemzőit mutatta be. Farkas és Vajda (1991) arra a következtetésre jutott, hogy a polgárok a legtöbb helyen a településen született, a helyi közéletben eddig is formális vagy informális vezetö szerepet betöltö́tt tekintélyt választottak polgármesterré 1990-ben. Bocz $(1995 ; 1996)$ szerint 1994-ben 74\%-ban korábbi polgármestert választottak meg, 1990-ben a polgármesterek $30 \%$-a volt korábbi tanácselnök, 53\%-a tanácstag; 1990-94 között 63\%-ról 74\%-ra nött a független jelöltek aránya, s a falvak a fugggetlen jelölteknek, a városok a pártjelölteknek szavaztak bizalmat. A régi és új döntéshozók a megválasztásukban szerepet játszó tényezöket különbözöképpen ítélik meg: az újjáválasztottak a lakóhelyükön végzett addigi munkájukra, az első alkalommal megválasztottak népszerüségükre, ismertségükre hivatkoztak leggyakrabban. Bocz szerint a helyben végzett munka és a lakóhelyi kapcsolatok voltak azok a tényezők, amelyek döntő módon befolyásolták a választások kimenetelét. A jelöltek képzettsége, illetve politikai irányultsága jóval kisebb mértékben gyakorolt hatást választási szereplésükre. 
Borboly István - Csite András : A polgármester, a falu meg a közösség :

Hozzászólás a „,üggetlen" polgármester vitához

Tér és Társadalom 13. évf. 1999/1-2. 109-128. p.

TÉT XIII. évf. 1999 1-2

A polgärmester, a falu meg a ...

111

A survey típusú adatgyüjtési módszert alkalmazó vizsgálódásokban nagy hangsúly helyeződött a polgármesterek pártszimpátiáinak feltárására (Bőhm-Táll 1993; Táll 1994; Szógyi 1993; 1994). Oláh (1996) a Veszprém megyében megválasztott polgármesterek adatait mutatta be, szerinte a településszerkezet a magyarázat arra, hogy mely megyékben van több fủggetlen polgármester (ahol több a kistelepülés, község). Kukorelli (1995) arra utalt, hogy a vállalkozók relatíve csekély jelöltkénti részvétele a választảsokon helyi társadalmi zavarokról tudósít. Bőhm és szerzótársai (1995) a pártszimpátiák és a vallási attitủdök kapcsolatát is vizsgálták, s kimutatták, hogy - ellentétben a fejlett demokráciákkal - a hazai polgármesterek körében e két tényező szoros összefüggésben áll egymással.

A független polgármesterek elsöprỏ sikere a két települési önkormányzati választáson nagyban hozzájárult a „pártosodás” jelenségkörének tematizálásához. A kilencvenes évek legelejének irásaiban (Horváth 1990; 1993; Kukorelli 1991a; 1991b; Pálné 1992; Velkey 1992) az a meggyöződés vált általánossá, hogy a helyi civil szerveződések a kistelepüléseken a nagyvárosoktól eltéróen müködnek, a falvakban az emberek személyekre szavaznak, nem úgy, mint a városban (3000 lakos felett általában „pártosak” az ơnkormányzatok). A kutatók egy része a pártosodás és a kommunitás elvének eltérő politikaszervező szerepét hangsúlyozta (Horváth 1996). Kulcsár (1996) meglátása szerint 1994-ben a többnyire pártokban artikulálódott „ideológiai” politikának kicsi volt a jelentősége. Szerinte a politikai pártok azért nincsenek jelen a kistelepüléseken, mert a települések közösségi vonásai, civil társadalmi jellege elegendőnek bizonyul az alkupolitikában, így a kőzvetítés során nincs szükségük többnyire ideológiailag befolyásolt pártszervezetekre. Szoboszlai (1996) is erre a meglátásra jutott, amikor kiemelte, hogy a pártok helyi szervezetei nagy önállóságnak örvendenek, a pártok közötti ideológiai kapcsolatok alig-alig jelennek meg a társadalomban, a közelséget-távolságot a személyes kapcsolatok dominálják.

A kommunitás elvén szerveződő kistelepülési önkormányzatok müködésének jobb megértése arra ösztönözte a kutatókat, hogy a pártok mellett azon (formális és informális) szervezödésekre fordítsák figyelmüket, amelyek szerepet játszottak az önkormányzati választások kimenetelének alakitásában. Kovács (1994) arra hívta fel a figyelmet, hogy a falun belüli ellentétek kifejezése a hagyományos kapcsolatokra épül. Tóth (1991) úgy értelmezte a családi, rokoni, szomszédság, ismerösi hálózatok helyi politikai szerepét, hogy a korábbi időszakban lezajlott funkcionális differenciálódás ellenére változatlanul összemosódnak az élettevékenységek és létszférák funkciói. Velkey (1994) empirikus kutatásai három olyan szervezetet mutattak ki, amelyek kinyilvánítottan politikamentesek, ám teret adtak spontán politikai megnyilvánulásoknak: az egyházak, a népfront és a mủvelődési központok. Németh (1991) Baranya megyei tapasztalatai azt mutatták, hogy a gazdasági fejlettség és a képviselőjelöltek száma között szignifikáns a kapcsolat: a prosperáló községekben a jelöltek száma háromszorosa is lehetett a többinek. Szógyi (1992) egy településen, a helyi választásokon a református és katolikus közösség szemben- 
Borboly István - Csite András : A polgármester, a falu meg a közösség :

Hozzászólás a "független" polgármester vitához

Tér és Társadalom 13. évf. 1999/1-2. 109-128. p.

állását regisztrálta, Gyenei (1992) pedig a cigányok helyi politikából történỏ sajátos kizárásáról tudósított.

A helyi társadalom nem pártelvủ, ám politikai szereppel (is) bíró szerveződéseit a kutatók egy része a „civil társadalom” fogalma segítségével látta megragadhatónak. Gergely (1992) szerint a civil társadalom az a társadalmi formáció, amely képes a tradicionális polgári szereptudat átvételére, érdekeit politikai szintérre hozni is alkalmas, és a politikai hatalommal szemben folyamatos oppozícióra rendezkedik be, anélkül, hogy törekvéseit mindenáron intézményesíteni akarná. Kukorelli (1991b) viszont arra utalt, hogy a civil szervezetek nem ritkán személyi ambíciók fedőszervei. Bőhm definíciója szerint ,... a civil társadalom világában az állampolgárok sajátos formális és informális csatornákon keresztül tevékenykednek autonóm célokat követve, önmagukat közösségé szervezve és öntevékenyen szolgálva saját érdekeiket" (Böhm 1996, 92).

A civil társadalom fogalma mellett a helyi társadalom és a lokális közösség kategóriái is a települési közösségek mibenlétét, a kommunitás elv politikaszervezó szerepét igyekeztek megragadni. Böhm szerint helyi társadalom ,...az egy-egy településen kialakult mezo-csoport, amely az individuum és a társadalmi egész között a primer csoportokon keresztül érdekeket, értékeket, ideológiákat közvetít, tradíciókat őriz és az autochton strukturálódás lehetőségét nyújtja” (Bóhm 1996, 15). Pálné arra utal, hogy „,.. a lokális közösség az emberek olyan területi, szomszédsági alapon szerveződő közössége, amely ơssztársadalmi meghatározottsága mellett elsősorban a földrajzi, ökológiai feltételekhez idomul, rendelkezik az elkülönült politikai részvétel, érdekérvényesítés esélyével, melynek közvetlen bázisát a lakóhellyel szemben támasztott igények, követelmények azonossága biztosítja" (Pálné 1990, 40).

A nagy adatgyüjtések feltárta eredmények magyarázata, a független polgármesterjelöltek sikere, a politikai pártok csekély falusi jelenléte, a lokalitás és kommunitás elv mủködésének feltárása a helyi politika és az országos politika közötti különbségek jellegének és okainak feltárását implikálta. Pálné (1992) a helyi hatalom sajátosságát abban látta, hogy az össztársadalmi tagoltsághoz képest egy másodlagos struktúrába rendeződik, ideológiai kötődése gyenge, lokalizmus jellemzi; pragmatikus, harmóniára törekszik, a törvényhozás-végrehajtás nem különül el élesen, valamint szembesül a kőzvetlen demokratikus módszerekkel. Böhm (1994) szerint a helyi politizálás lényege, hogy az kevésbé ideológikus és átpolitizált, mint a nagypolitika. Szoboszlai (1992) úgy vélte, hogy helyi szinten szinte teljesen ismeretlenek az érzelmi-indulati különbségek azon jegyei, amelyek olykor teljesen megbénítják a parlamenti egyưttmüködést.

Ezek az elemzések számos ponton új ismerettel gazdagitották a falusi politizálásról meglevő tudásunkat, a kialakult fogalmi keret és a mögötte meghúzódó előfeltevések ugyanakkor gúzsba is kötötték a helyi vizsgálódásokat. A helyi politizálás sajátszerủségét a kutatók többsége a civil, önkormányzati, nem pártelvủ, decentralizáció, közösség fogalmak segítségével igyekezett megragadni, s ezzel nagyban hozzájárult ahhoz, hogy az „országos” és a „helyi” politizálás, mint két, elveiben, 
Borboly István - Csite András : A polgármester, a falu meg a közösség :

Hozzászólás a „független" polgármester vitához

Tér és Társadalom 13. évf. 1999/1-2. 109-128. p.

TÉT XIII. évf. 1999 — 1-2

A polgármester, a falu meg $a$...

szervezödésében alapvető különbségeket (s szembenállást) felmutató valóság jelenjen meg. Elemzésünkben a helyi, falusi politikai mezö „országostól” eltérö szerveződését nem előfeltevés jellegü adottságként tételezzük, hanem annak jobb megértéséhez szeretnénk hozzájárulni, hogy a helyi politizálás országosétól eltérö jellege miként konstruálódik. E törekvéseink megvalósításához a fentiektö1 eltérő kutatási programokhoz kell csatlakoznunk. A következö fejezetben Pierre Bourdieu nagy hatású nyelvszociológiájának néhány föbb meglátását ismertetjük, kérdéseink feltevésében és megválaszolásában az általa megalapozott kutatási tradíció eredményeire épitettünk.

\section{Elméleti keretek: Pierre Bourdieu nyelvszociológiája}

A politika diszkurziv értelmezésének lehetőségeit kutató elemzések (pl. Szabó 1996; 1997a; 1997b; Csigó 1997) a politikai szociológia azon cselekvés-, intézmény- és szervezetelméleti hagyományainak szoritásából kívánnak kitörni, amelyek valamely elméleti ,szempontból preformált politikai valóság részeként értelmezik a politika nyelvi valóságát" (Szabó 1996, 103-104). A politikai valóság konstruált voltát feltételezve, annak beszédközpontúságát, diszkurzusbeli konstruálását hangsúlyozzák. Az ez irányú vizsgálatok elméleti megalapozásában Pierre Bourdieu munkái játsszák az egyik kiemelkedő szerepet.

Pierre Bourdieu (1985; 1986; 1991) (Pokol 1997) a nyelvet társadalmi és hatalmi jelenségként értelmezi, $s$ úgy véli, hogy a nyelv müködésére piaci törvényszerüségek érvényesek. A nyelvhasználat társadalmi cselekvést jelent, amikor az ember beszél, akkor társadalmi viszonyokat és pozíciókat hoz létre. A társadalmi viszonyok nyelvi konstruálása a társadalom integrálásában játszik kitüntetett szerepet, mivel a nyelvhasználat révén a társadalom világát felosztják, megnevezve azonosulási pontokat és különbségtételeket hozva létre.

Az etnikai és regionális önállósodási törekvéseket vizsgáló munkájában Bourdieu amellett érvelt, hogy a régió és az etnikum sajátosságainak, eredetének keresése nem a meglévő, ám feledésbe merült dolgoknak az újrafelfedezése, hanem társadalmi konstruálási folyamat, azaz különböző társadalmi szereplök (tudósok, müvészek, politikusok stb.) közti definiálási küzdelem. A küzdelem tétje, hogy a legitim, de legalábbis domináns definíciót ki hozza létre, $\mathrm{s}$ ezzel $\mathrm{ki} / \mathrm{mi}$ válik az adott helyzetben hatalommal bíró társadalmi szereplövé. A társadalmi világ legitim definíciója így csoportok létrejöttének, illetve eltünésének forrásává is válik.

Bourdieu a politikai mező struktúráját objektív erőviszonyok tagolt rendszerének tartja, $s$ úgy véli, hogy a mezöben zajló cselekvések a meglevő struktúrák fenntartására, illetve megváltoztatására irányulnak. A képviseleti jellegủ modern politikai mezỏ alapviszonyára, a politikus és választó közötti viszonyra a megbízott és megbízó közötti kapcsolat a jellemző. A „,megbízás” választást jelent a politikusok által felkínált percepciós kategóriák, a társadalmi világ észlelésének és kifejezésének eszközei közül. Bourdieu szerint a politikusok monopolizálják a politikai termékek elóállítását, azaz a választás a megbizó oldaláról passzív jellegü elfogadást jelent. 
Borboly István - Csite András : A polgármester, a falu meg a közösség :

Hozzászólás a "független" polgármester vitához

Tér és Társadalom 13. évf. 1999/1-2. 109-128. p.

114 Borboly István-Csite András

TÉT XIII. évf. 1999 1-2

A nyelvi formákat, jelentéseket és értelmezéseket termelö politika nemcsak a létezỏ világot (milyen folyamatok észlelhetők körülöttünk), hanem a lehetséges, elgondolható világot is tematizálja. Ugyanakkor az elvont lehetöségek realizálása azon múlik, hogy az egyes csoportok miként férhetnek hozzá a megvalósításhoz szükséges eszközökhöz. A csoportok közti egyenlötlenségek azonban oda hatnak, hogy az ősszes elgondolható világ közül csak néhány juthat el a megvalósítás lehetöségéig.

A politikai csoportok egyenlőtlen hatalmi viszonya mellett a mező „rigiditásához" az is hozzájárul, hogy a politikai küzdelemben az észlelési formák legitimmé tételéért és intézményesitéséért folyik vetélkedés. A legitimmé vált észlelési és kifejezési formák visszahatnak, korlátozólag lépnek fel a mindenkori jelenben, mivel újratermelésüket a már hatalmi pozícióban levő vélemény-csoportosulások igyekeznek a létrehozott intézmények segítségével fenntartani, s a rivális észlelési kategóriarendszerrel fellépő, kihívó csoportokat háttérbe szorítani.

A politikus, mint a választók képviselöje nem pusztán mások helyett cselekszik, hanem önállósodhat megbízóitól, s nyelvi cselekvések sorozatával kísérletet tehet megbízói csoportjának átdefiniálására, a csoport önazonosságánák átformálására.

\section{Vizsgálatunk eredményei}

Választott „adatgyüjtési” módszerünk, a lazán strukturált interjúkkal történö információszerzés nem tudta a maga totalitásában megragadni, hogy egy-egy faluban miként folyik a politizálás, a mindennapi életet miként szövik át a politikai relevanciával is rendelkező megnyilvánulások, miként jelölödik ki a politikai és nem politikai megnyilvánulások határa, miként megy végbe a politikai jelentésadás, $s$ hogy kik vesznek részt a frontvonalak aktuális megállapitásában. Szándékunk csupán annyi volt, hogy bepillantsunk a helyi politika-csinálás ,laboratóriumába” (Latour 1987), adalékokat kapjunk a falusi politizálás kulcspozíciójában levő polgármesterek politika-csináló szerepének jobb megértéséhez.

Két térségben készítettünk interjúkat a kistelepülések polgármestereivel: a Tatabányát és Tatát körülölelö térségben és az Egertől délre fekvő, Egerhez közeli falvakban. Adatgyújtésünk nem azzal a céllal készült, hogy a „tipikus magyarországi falusi polgármester" jelentésadási, értelmezési stratégiáját bemutathassuk. Az itt következő elemzést inkább heurisztikus erejünek tekintjük, mely a további kutatásokhoz adalékkal szolgálhat.

Az interjúk készítése során leginkább arra voltunk kíváncsiak, hogy a polgármesterek mit tartanak érdemesnek megemlíteni falujukról, az ott élö emberekről, illetve saját tevékenységükről és az önkormányzat müködéséről. Az interjúk során arra törekedtünk, hogy a polgármesterek által fontosnak tartott kérdések kerüljenek előtérbe. A következőkben azokat a témákat, 'személyeket és helyi társadalmi csoportokat vesszük sorra, amelyek, és akik tematizálódtak a beszélgetések során. Természetesen mind a két kistérség, mind az egyes polgármesterek között jelentős érvelési mintázatbeli „eltérések” mutatkoztak, ezekre az egyes témák esetében utal- 
Borboly István - Csite András : A polgármester, a falu meg a közösség :

Hozzászólás a „független" polgármester vitához

Tér és Társadalom 13. évf. 1999/1-2. 109-128. p.

TÉT XIII. évf. 1999 - 1-2

A polgármester, a falu meg $a \ldots$

ni fogunk. A témák, személyek, csoportok elemzésében arra is kitérünk, hogy ezek milyen kontextusba ágyazottan jelentek meg a polgármesterek érvelésében.

Infrastruktúra, beruházások: gáz, telefon, viz, szennyviz, tornaterem stb.

A vizsgált településeken a kilencvenes évek elején komoly infrastrukturális beruházásokat hajtottak végre. A gázhálózat kiépitésében a polgármesteri hivatalok is aktívan részt vettek. Legtöbb helyen banki kölcsönt vettek igénybe a vezetékrendszer kiépítéséhez, s a lakosságot különbözö kedvezmények felkínálásával ösztönözték a bekapcsolódásra. Ez nem mindenütt ment könnyen, általános volt, hogy a képviselőtestület tagjai és az „aktívabb emberek” utcákra, körzetekre osztották egymás közt a falut, s ki-ki saját térségében felkeresett minden családot a gázberuházáshoz való csatlakozást ösztönözvén. A legföbb érv az volt, hogy amennyiben most nem használják ki az állami támogatást, nem tudható, mikor kínálkozik erre ismételten lehetőség. A lakosság meggyözésében az is nagy hangsúlyt kapott, hogy a gáz fejlettebb, kényelmesebb fútési megoldás, mint a fa vagy a szén, s így az emberek életkörülményei nagyban javulnak, közelítenek a városihoz.

Számos faluban építettek a kilencvenes évek első felében tornatermet. A beruházás elfogadtatásában itt is fontos szempont volt a kedvezó lehetőség kihasználása, továbbá annak az igénynek a megfogalmazása, hogy ha a szomszéd településeken építenek tornatermet, akkor azoktól „nem szabadna lemaradni”. A helyi iskolaépületek rekonstrukciójában, a helyi postahivatal és önkormányzati épület felújitásában, illetve néhány helyen létrehozásában, a „teljes értékü falu” kialakításának igénye öltött testet.

\section{Pártok}

A politikai pártok a polgármesteri interjúkban két kontextusban jelentek meg: egyrészt a helyi politikai élet bemutatásakor, másrészt a „nagypolitikával" való kapcsolat (hiányának) tematizálása során. A helyi politikában a pártok közül az MDF, az MSZP, a Kisgazdapárt, az SZDSZ és a Vállalkozók Pártja volt jelen. Tevékenységük a választások időszakában élénkưl fel, majd „elhallgatnak”. Egyes településeken a polgármester „hivatalból” meghívja a pártok képviselöit a testületi ülésekre, ám csak tanácskozási joggal. A testületi ülések állandó meghívotti körébe azonban nemcsak a helyi pártszervezetek, de a sportegyesület, az iskola, a hagyományőrzö egyesủlet vezetői is beletartoznak. Néhány helyen az önkormányzat a faluházban adott helyiséget a pártszervezeteknek, így azok egymás mellett, „békésen megférve" tevékenykednek. A pártszínekben indult polgármesterek zöme vagy a „,kisgazdák”, vagy az „emdéefesek” közül kerültt ki. A kisgazdaszervezetek általában nem az idős tagság soraiból jelöltek polgármestert, hanem megkértek egy „fiatalabbat”, vállalja el a jelölést, ,jöjjön haza”. A „nagypolitika” két témakörben kapott említést: egy-egy vezetö politikus helyi látogatása kapcsán, illetve az országgyülési képviselővel való kapcsolattartásban. Noha általános az a vélemény, hogy „ott fenn az önkormányzatokkal nem sokat foglalkoznak”, ám a vezetö politikusok helyi „fóruma” kapcsán a magas látogatottságot megemlítették. 
Borboly István - Csite András : A polgármester, a falu meg a közösség :

Hozzászólás a "független" polgármester vitához

Tér és Társadalom 13. évf. 1999/1-2. 109-128. p.

\section{Viták}

A legtöbb helyen nincsenek konfliktusok, csak viták, melyek a falu jövöjéről folynak. Konfliktusok két témában fordulnak elö a polgármesterek szerint: a települések között és a „nagypolitikában”. A települések közötti konfliktusok forrása a közös intézmények (iskola, óvoda, orvos, szociális intézmények) finanszírozása. A vizsgált településeken szinte mindenütt van iskola, ám a gyermeklétszám csökkenése és az „elcigányosodó” iskolák népszerütlensége miatt az iskola fenntartásának igénye a tanulókért való versenyre ösztönzi az önkormányzatokat. A közös intézmények finanszírozásának kormányzati támogatása ellenére, a helyi önkormányzatok igyekeznek a saját iskolát, óvodát önállóan fenntartani.

A falun belüli konfliktusokra való rákérdezésunk heves ellenkezést váltott ki. A megkérdezett polgármesterek szerint „szakmai viták” vannak ugyan, például olyan kérdésben, hogy felújítsák-e az óvodát, ám ezek nem nevezhetők konfliktusnak.

\section{Hagyományok}

A hagyományok a községek reprezentatív történeti múltjának termelésében és újratermelésében játszanak nagy szerepet. Mindkét térségben számos sváb nemzetiségủ falu található, ám a hagyományok ápolásában a két térséget jelentös különbségek jellemzik. A Komárom-Esztergom megyei „sváb” községekben hagyományộrző egyesületek müködnek. A szinte mindenütt elöforduló tủzoltó egyesületek mellett a községi zenekarok, illetve az idősek kórusa az önkormányzat állandó támogatását élvezi, képviselőik a testuleti ûlések állandó meghívottjai. A kilencvenes évek elején újra létrehozott helyi hagyományőrző egyesületek a „negyven éve” megszakadt hagyomány folytatói, létük természetes, és büszkeséggel tölti el a polgármestert. A sváb községekben azért is kap különös jelentőséget a hagyományörzö egyesület, mert a közösségi rendezvények (a betelepülésre és a kitelepítésekre való megemlékezések, falunapok) állandó szervezői és előadói. A kitelepítésekre való megemlékezéskor hazatérnek a Németországba deportált hajdani falubeliek, s ilyenkorra kicsinosítják a falut. A hagyományok fontosságát, a múlt jelentőségét a polgármesterek azzal is kifejezték, hogy a beszélgetések elején a község bemutatását a község múltjának felvázolásával kezdték. A sváb községekben a helyi időszámítás két fontos dátumaként a betelepulés és a kitelepítés éve jelent meg. A magyar többségu községekben a község története az elsỏ okleveles említéssel kezdődik, majd a község vallási összetetelét és a falu történeti jellegét (uradalmi, nemesi, paraszti) említették. A magyar községekben a helyi megemlékezések a nagy történeti eseményekhez (március 15., augusztus 20.), illetve a falu templomának búcsújához kötődnek. Az 1996-os millecentenáriumi megemlékezések kapcsán minden faluban „történt valami”, számos helyen fakeresztet állítottak, $s$ volt, ahol egész fasort ültettek az ünnep alkalmával, s a lakosok egy-egy fát „vásároltak”, vállalva annak gondozását.

A község hagyományainak ápolásában nagy jelentősége van a templomok rendbehozatalának és a nagyobb unnepek alkalmával tartott Istentiszteleteknek is. Ahol vegyes felekezetủ a lakosság, ott vagy ökumenikus Istentiszteletet tartanak, vagy 
egyik templomból átvonulva a másikba, egymás után tartanak megemlékezést. Az önkormányzatok kulturális költségvetésükböl támogatják a megemlékezéseket, a nevezetes napok megünneplését a kulturális bizottságok készítik elö.

A községek nemzetiségi karakterének meghatározása és folytonos megjelenítése, reprezentációja gazdasági jelentőséggel is bír. A kisebbségi önkormányzatok állami támogatásban részesülnek, a sváb települések németországi segélyekhez is hozzájutnak. De az is fontos szempont, hogy ahol nincsenek természeti értékek (tó, barlang stb.), ott a falusi turizmus szempontjából a hagyományok megjelenítése, mint községi kulturális termék szerepel. Szinte minden faluban készítettek a falu történetét, nevezetességeit bemutató magyar, német, esetleg angol nyelvủ prospektust.

\section{Romák}

A megkérdezett - némely esetben nemzeti kisebbségi - polgármesterek egy része arról számolt be, hogy „hála Istennek nálunk nincsen stnikum”. Ha mégis él a faluban kisebb lélekszámú roma közösség, akkor az csak egy-egy család, s azok „helybeliek, nincs velük gond, mindenki ismeri öket". A települések másik részében a lakosság 10-20\%-a roma. A cigányok problémaként való említése három témához kapcsolódott: az iskola, a szociális segélyek és a búnözés kérdésköréhez. Az iskolában a roma gyermekek jelenléte azért okoz problémát a polgármesterek szerint, mert az „elcigányosodó” iskolából a nem roma szülők gyermekeiket más iskolákba viszik, a pedagógusok között kontraszelekció indul meg, $s$ az intézmény finanszírozása is megnehezül, több forrást igényel. A szociális segélyezésben a nem roma lakosság „nem nézi jó szemmel”, hogy a cigảny segélyezettek a támogatások ,99 százalékát elviszik”, noha lélekarányuk csak „10 százalék”. Mivel „a cigányok nem dolgoznak, s sokan italra költik a segélyt", ezért sok faluban természetben vagy levásárolható kuponok formájában nyújt az önkormányzat támogatást. A képviselötestületek mindenütt szociális bizottságot állítottak fel a segélykérelmek elbírálására. Ahol volt roma kisebbségi önkormányzat, ott ennek képviselöjét is bevonták a döntéshozatalba. A bünözés és a roma lakosság jelenléte közötti összefüggés felvázolása minden interjúban elöfordult. A probléma jelentőségét a mezei lopások arányának és a betörések számának növekedésével támasztották alá a megkérdezettek. Az Eger környéki települések némelyikén, ahol jelentős a víkendházak száma, a betörések nagy száma miatt a falu idegenforgalmi vonzerejének csökkenését valószínüsítették. Csak néhány polgármester hozta a roma lakosság problémáit azzal összefuiggésbe, hogy a rendszerváltást követően ,kikerültek a munkahelyekröl, s most senki sem akarja öket felvenni, mert cigányok".

\section{Tanárok, iskola, értelmiség}

A tanárok kapcsán az egyik legfontosabb momentum az, hogy „az értelmiség a faluban van-e". Eger környékén a tanárok jelentős része nem a településen él, hanem a megyeszékhelyről jár ki naponta. Az ingázók nem igen tudnak részt venni a község életében. Az iskola helyi funkciója - az oktatás mellett - a falu kulturális életének szervezése. Különösen a sváb településeken számoltak be a polgármeste- 
Borboly István - Csite András : A polgármester, a falu meg a közösség :

Hozzászólás a "független" polgármester vitához

Tér és Társadalom 13. évf. 1999/1-2. 109-128. p.

rek arról, hogy a tanítók, tanárok nagy szerepet játszanak a helyi hagyományőrző egyesületek működésében. Az önkormányzat kulturális bizottságában az iskolaigazgató szinte mindenütt jelen van meghívottként.

\section{Város}

Interjúinkban a város két kontextusban jelent meg: egyrészt, mint a község és a szomszédos város kapcsolata, másrészt az életkörülmények városiassá tételeként, mint az egyik fö polgármesteri teendő. Heves megyében az egri önkormányzat igyekszik a környező települések önkormányzataival szoros együttmüködést kialakítani. „Eger nélkül nem lehet gondolkodni” sem a munkahely-teremtésben, sem a közmü-beruházásokban. Tatabánya, Tata és Oroszlány - néhány kivételtől eltekintve - a vizsgált településektől viszonylag nagyobb távolságban helyezkedik el, s a kapcsolatok sem intenzivek. „Jó lenne, ha újra beindulna valami”, de egyelöre még nincs erre kilátás. Az utóbbi években a vizsgált községek szinte mindegyikében megjelentek a városból kitelepülő fiatalok, akik a faluban épitettek házat, ám többségük a városban dolgozik. Több településen új területeket közmüvesítettek, s a kedvezmények hatására növekszik a népesség. Több polgármester is amellett érvelt, hogy körülbelül 3000 fóig kellene növelni a lakosság számát, mert akkora népességet a helyi intézmények még képesek ellátni. A „külvárossá" válást többen is megfogalmazták hosszabb távú célként. A kábelek föld alatti vezetésével már azt szeretnék elérni, hogy a település „kívülről” is hasonlítson a külvárosokhoz.

\section{Alkalmasság}

Arról, hogy milyen tényezők játszottak szerepet polgármesterré választásában, mi tette alkalmassá a feladat elvégzésére a falu lakosságának többsége szemében, meglehetősen egységes kép látszik kibontakozni. A községből való származás, a tősgyökeresség, a rokoni kapcsolatok, a korábbi közösségi tevékenység, valamint a szakmai hozzáértés azok a tényezők, amelyek szinte minden polgármester beszámolójában előfordultak. A helyi születés, a helyi munkásság azért fontos, mert „, ismerik az embert, a családját, a magatartását”. Tudják, hogy az apja „komoly ember" volt-e, s ő maga a korábbi évtizedekben "hogyan viszonyult a faluhoz". A helyi születés választások-kori szerepére utal az is, hogy a szomszéd településen is odavalósi embert igyekeztek megválasztani polgármesternek: a sváb településeken svábot, a magyarban magyarokat. A rokoni kapcsolatok két szempontból voltak befolyásolói a választási szereplésnek. Egyrészt a nagyobb családok tagjai igyekeztek támogatni a „közülük való” jelöltet. Másrészt az is előfordult, hogy a kisgazdák támogatásával induló, az FKGP helyi tagságához képest „fiatal” jelöltet a kisgazda családok támogatták. A korábbi közösségi tevékenység a helyi sportegyesületben való aktív részvételt, illetve a szakszervezeti, tanácsi múlt felemlegetését jelenti. A helybeliség és a rokoni kapcsolatok azonban csak a sikeres szereplés lehetőségét adják, a választási kampányban olyan magatartást kell a jelöltnek felmutatnia, amely bizonyítja, hogy a „kisemberek pártján áll”, „versenynek, nem pedig harcnak tekinti a kampányt”, olyan versenynek, ami a falu színe elött a problé- 
Tér és Társadalom 13. évf. 1999/1-2. 109-128. p.

mák jobb megoldásáért való érvelésben ölt testet. Nem feledkezhetünk meg ugyanakkor arról sem, hogy a választási kampányban olyan érvek is elhangzottak, amelyek a falu konkrét problémáihoz kơtődtek. Így például egy helyütt a megbízhatóság bizonyítása kapott nagy szerepet a kampányban, mivel a korábbi polgármesternek „piszkos pénzügyei voltak”. Másutt a testületi tapasztalatok kaptak jelentőséget, mivel a rivális jelöltnek nem volt igazgatási múltja, nem tudott a „konkrét problémákra konkrét válaszokat adni”. A választási kampány elsỏ fázisában számos telepưlésen több jelölt is volt, de a választási cédulára csak egy vagy két jelölt neve került fel: a választást megelözö vitákban azok rostálódtak ki, akik úgy ítélték meg, hogy nincs esélyuuk a sikerre.

\section{Szociális segély}

A szociális segélyezés témája leginkább az öregekhez és a romákhoz kapcsolódik. A nyugdíjas, segítségre szoruló idős emberek gondozását a legtöbb település idősek otthona fenntartásával, vagy speciális gondozó foglalkoztatásával oldja meg. Mindenütt elfogadott, hogy az időseket segíteni kell, ám, hogy ennek a költségvetés mekkora részét kell kitennie, arról komoly viták vannak az önkormányzatokban. Mindazonáltal ez olyan kérdésnek számít az „elơregedô” településeken, melyben nagy óvatosság jellemzi a polgármestereket, $\mathrm{s}$ igyekeznek az öregek gondozására létesített intézmények folyamatos fenntartását biztosítani. A jövedelempótló támogatások, illetve az egyszeri szociális segélyezés helyi gyakorlata viszont talán az egyik legfontosabb vitatéma. Mind a roma lakosság segélyezettségének nagyobb aránya, mind a roma és nem roma, de „helytelen életmódot” követő emberek megregulázása a helyi emberek ,igazságérzetének" eleget tevő gyakorlat kialakítására ösztönzi az önkormányzatokat. A szociális segélyekkel az önkormányzatok „csínján bánnak”, igyekeznek minél nagyobb részt természetben kiadni, így nehezitvén meg, hogy a segély „a kocsmában kössön ki”. A szociális önkormányzati bizottságok "olyanokat is támogatnak, akiket nem kellene", amennyiben viszont lehetöség van a kérelem elbírálására, úgy igyekeznek a „jogos és nem jogos” igények kőzötti kulönbségtételre. „Vannak olyan emberek, akik önhibájukon kívül jutottak átmenetileg nehéz helyzetbe, de olyanok is vannak, akik nem is tesznek semmit helyzetük javítására."

\section{Falu, közösség}

„Paraszti ésszel gondolkodnak a népek a faluban, jó felé terelik a dolgokat. Ezek megmondják, hogy fiam, ülj nyugton...”. A falut, a falukőzősség milyenségét a polgármesterek az ơnkormányzat és a falu, az emberek kapcsolatát bemutatván fejtették ki. „Ha a polgármesterrel nem húz együtt a falu, akkor eláshatja magát az ember." A polgármester, a képviselőtestület és a falu kapcsolatának „csapatként" való jellemzése, az „egy irányba húzás” minden interjúban elöfordult. Az önkormányzat, a polgármester igyekszik segíteni a bajban levőknek, de az emberek is tisztelettel, a szükséges elismerés megadásával tekintenek az önkormányzat munkájára. A polgármesterek szerint mindenhol vannak ,hangoskodó” emberek, de 
Borboly István - Csite András : A polgármester, a falu meg a közösség :

Hozzászólás a "független" polgármester vitához

Tér és Társadalom 13. évf. 1999/1-2. 109-128. p.

nekik nem velük, hanem az „,egyszerü” emberekkel kell a dolgokat megbeszélni. A hangoskodás negatív megitélése abban is tetten érhetö, hogy az egyik településen az új polgármester elsö feladataként ,igyekezett rendet rakni” a hivatalban, s rávenni az ott ügyeiket intézöket arra, hogy ,ne hangoskodjanak, csendesen is lehet a dolgokat intézni".

A falvak ,erkölcsi tartása" miatt a betelepülök nem tudják felborítani a falu életét. A gyenge településeket elhagyják az emberek, de az erös, erkölcsös községekbe inkább újak, fiatalok érkeznek. Az erös település egyik megnyilvánulása az is, hogy „megélnek egyedül is”, nincsenek rászorulva más községekkel való együttmüködésre, közös intézmények kialakítására.

\section{Polgármester}

A település első emberét mindenki keresztnevén szólítja, nem pedig „polgármester úrnak”. A polgármester „belelát” az emberekbe, tudja, hogy vannak olyanok, akiknek semmi sem jó. A polgármesternek tudnia kell bánni az emberekkel, meg kell értetnie magát velük, azokkal is egy véleményre kell jutnia, akik „más értelmi szintüek". A szavahihetőség, a személyes kapcsolattartás, a mintaadás, az élenjárás olyan követelmények, amelyeknek meg kell felelni. Akinek ez nem sikerül, az elveszti az emberek bizalmát, s hamar „beskatulyázzák”.

A polgármester feladata nagyban különbözik a „nagypolitikával” foglalkozókétól. Távirányítással nem lehet irányítani, a faluba kell költöznie annak, aki vezető akar lenni. ,A Demszkynek nem kell azokkal találkoznia, akikről dönt”, de a falusi polgármesternek igen. Minden cselekedetét figyelem kíséri, minden lépését el kell magyaráznia, $\mathrm{s}$ igyekeznie kell mindenkivel megértetni magát. Az emberek a vezetöjelöltben a személyiségét vizsgálják, azt, hogy mennyire alkalmas a feladat elvégzésére. „Itt egy a cél, ha valamit meg kell csinálni, akkor a kérdés az, hogyan csináljuk meg."

\section{Betelepülök}

A megkérdezett polgármesterek nagyobb része arról számolt be, hogy a falura inkább a betelepülés a jellemző, semmint a lakosság fogyása. Noha vannak olyan települések, ahol elöregedik a lakosság, de ott is igyekeznek számos eszközt megragadni a fiatalok helyben maradásának, letelepülésének ösztönzésére. Ahol már nagyobb létszámban érkeztek városról (vagy Erdélyből) „,betelepülők”, ott a polgármesterek arra utaltak, hogy gazdaságilag jót tett a községnek (mert a normatív támogatás nőtt), de érzelmileg már kevésbé, mert a „betelepülők nem foglalkoznak a faluval". Erdélyiek több községbe is nagyobb számban érkeztek a nyolcvanas évek végén, a kilencvenes évek elején. „Az ingben-gatyában jötteket kezdetben a község befogadta, de amikor három-négy év után sorra vettek vagy építettek házat, akkor megharagudtak rájuk. Más 20 évig gürcölt érte." 
Tér és Társadalom 13. évf. 1999/1-2. 109-128. p.

\section{Vállalkozók}

A polgármesterek számára a vállalkozók a helyi társadalom egyik legfontosabb csoportját jelentik. Az egyesületekhez, közintézményekhez, pártokhoz hasonlóan a vállalkozók szervezeteivel - ha van ilyen a faluban - a képviselötestület intézményesített kapcsolatot tart fenn. Ahol a vállalkozóknak nincs szervezetük, ott rendszeres egyeztetések, fórumok folynak az önkormányzat és az iparosok, kereskedök között. A Komárom-Esztergom megyei településeken az országos átlagnál magasabb a vállalkozások egy före jutó száma. Sok helyultt minden harmadik háztartásban van vállalkozói engedéllyel rendelkezỏ iparos, kereskedö. A Heves megyei településeken viszont az őstermelök (szőlös- és kertészgazdák) alkotják a helyi önfoglalkoztatók legnagyobb csoportját. Az önkormányzat vezetése - a polgármesterek elmondása szerint - a vállalkozásokat a jövőbeli fejlödés egyik zálogának tartja. Az iparlízési adó kiszabásánál fontos szempont volt, hogy meghallgassák a vállalkozók véleményét, $\mathrm{s}$ az adó nagyságát a még elviselhetó kereteken belül jelöljék ki. „Belölük élünk, meg lehet ỏket sarcolni, de ha kérek valami segítséget, akkor biztos nem fognak segíteni."

A vállalkozások sikerét a maga eszközeivel az önkormányzatok is igyekeznek elómozdítani. A városinál gyorsabb ügyintézést, iparüzési adókedvezményt és önkormányzati megrendeléseket kínálnak a helyi iparosoknak. Ugyanakkor a polgármesterek arra is utaltak, hogy a vállalkozók többségének „még sokat kell fejlödnie”: egyrészt szervezeteket kellene létrehozniuk, hogy legyen kivel megtárgyalni a problémákat, másrészt jobb, erösebb adófizetőkké kellene válniuk. A külföldi illetve hazai, de nem helyi vállalkozók faluba vonzása is komoly prioritás a polgármesterek tevékenységében: „ha jött egy kulföldi, azon voltunk, hogy megfogjuk, bemutassuk neki a települést". A külföldi testvérközségi kapcsolatok, az idegen nyelven kiadott prospektusok, a helyi egyesúletek nemzetközi kapcsolatainak segítése mind-mind e cél megvalósítására irányulnak.

\section{Szomszéd település}

A fentiekben már utaltunk rá, hogy a polgármesterek a falun belüli kủlönböző véleményeket vitaként jellemezték, míg a települések közötti vitákat konfliktusként. Néhány kivételtól eltekintve a legtöbb település vezetése - ha teheti - kerüli a szomszéd községekkel való együttmúkơdést. Sok példája van annak, hogy az iskola, a szemétszállítás stb. megszervezésében „racionálisabb”, a települések együttmüködésére épülö megoldások is elképzelhetők lennének, ám a szocialista időszak társközségi kapcsolata, valamint a komplett intézményrendszerrel „felszerelt” falu létrehozásának jelenkori igénye ellene hat a kooperációnak: „mi csendes résztvevők akarunk lenni" a most szerveződő kistérségi együttmüködésben. A hajdani társközségek polgármesterei a falu múltjának bemutatásakor nem feledkeztek meg kitérni arra, hogy, itt nem voltak fejlesztések, mindent magunknak kellett az elsö időben megcsinálni". Nem felejthetjük el, hogy az 1994-es választási kampányban a község önállóságát helyreállító, iskolát, óvodát, kőzségi hivatalt, postát építtetö polgármester maga melletti egyik fö érve a négy évben végrehajtott fejlesztés volt. A 
Borboly István - Csite András : A polgármester, a falu meg a közösség :

Hozzászólás a "független" polgármester vitához

Tér és Társadalom 13. évf. 1999/1-2. 109-128. p.

községek közötti fejlesztési verseny egy-egy beruházás lakossági elfogadtatásában is fontos érv. Ha a szomszédban már bevezették a gázt, csatornáztak, vagy tornatermet létesítettek, akkor a „falu önbecsülésének” megörzése érdekében ezeket helyben is meg kell valósítani. A fejlesztési versenynek van egy olyan része is, amely kifejezetten a betelepülökért folyik. Gyakran hangzik el egy-egy falugyülésen, testületi ülésen, hogy a letelepedni kívánókat azért kell segiteni, mert a szomszéd faluban, ahol ezt nem teszik, elöregedik a népesség. A lakosságszám csökkenése az intézmények fenntartását veszélyezteti, arról nem is beszélve, hogy az önkormányzatok az állami normatíva egy részét lakosságuk nagysága szerint kapják.

Ahol olyan példát találtunk, hogy a szomszéd községek együttmüködnek, ott a falvak már összenőttek. A képviselötestületek közös üléseket tartanak, minden kérdésben egyeztetnek, „egy faluról van itt szó”, azonban ,akik Pesten az ügyeket irányítják, azok nem tudják, hogy a két falu egyben van, gózük sincs, hogy itt mi van...". Így ezeken a településen mind az együttmüködésből, mind pedig a hivatalos különállásból származó pénzügyi elönyöket realizálni tudják.

Jövõ

A falu jövöbeli sikerességének zálogát, az elkővetkező időszak feladatait a polgármesterek szinte azonosan ítélték meg: egyrészt az infrastrukturális beruházások befejezésében (szennyvíz, út), másrészt a lakosság elöregedésének megállittásában, fiatalok letelepítésében, harmadrészt pedig az emberek „,szemléletváltásában, önállósodásában".

$\mathrm{Az}$ elmúlt években kialakított intézményeket minden polgármester fenn kívánja tartani, a szennyvíz-kérdés megoldása és az utak rendbetétele pedig a két legfontosabb hosszabb távú teendő. „Energia oldalon sok pénz van”, szigetelni kell a házakat, s ebben számítanak állami programok beinditására is. A sportcentrum, az iskolai számítógépes és nyelvi labor létesítése már olyan feladatnak tekinthető, ami szorosan kapcsolódik a „fiatalítás” programjához. A helyi életkörülmények városi szintre hozása mellett a fiatal családok helyben maradása és betelepülése érdekében a gyermekek magas szintủ oktatását lehetővé tevő iskola kialakítását kiemelten kezelik a polgármesterek. A fiatalítás egyrészt a létrehozott intézmények müködtetését tenné lehetővé, másrészt az önkormányzati bevételeket is növelné. Az önkormányzati tulajdon (elsősorban ingatlanok) sikeres menedzselése a helybéli emberek számára is kínál elönyöket: munkahelyet, növekvő ingatlanárakat, több helyi szolgáltatást. A helyi idegenforgalmi potenciál növelése, látványosságok kreálása (ünnepségek, emlékhelyek, falumúzeumok, szórakoztató rendezvények, tavak kihasználása stb.) szintén azt jelzi, hogy a polgármesterek java az önkormányzat tevékenységét a szúkebb értelmü közigazgatáson kívul a helyi gazdaság fejlesztése, a településmarketing felé kívánja kiterjeszteni: „elöször az infrastruktúrát kellett rendbe tenni, aztán jöhetnek a külföldiek, a városiak". 
Borboly István - Csite András : A polgármester, a falu meg a közösség :

Hozzászólás a "független" polgármester vitához

Tér és Társadalom 13. évf. 1999/1-2. 109-128. p.

TÉT XIII. évf. 1999 a 1-2

A polgármester, a falu meg a ...

\section{Érvelési stratégiák}

\section{Kulcsfogalmak}

A polgármesterekkel készített interjúk során elötérbe került témák, társadalmi csoportok, helyi problémák, ügyek (issues), azaz a polgármesterek beszédének kulcskategóriáinak egymáshoz kapcsolódását az 1. ábra jeleníti meg. Az ábra egyfajta összefoglalás, azaz a leggyakoribb kapcsolatokat mutatja.

\section{1. ÁBRA}

A polgármesterek beszédében használt kulcskategóriák kapcsolódási hálója (Network of Key Categories Used in Speech of Mayors)

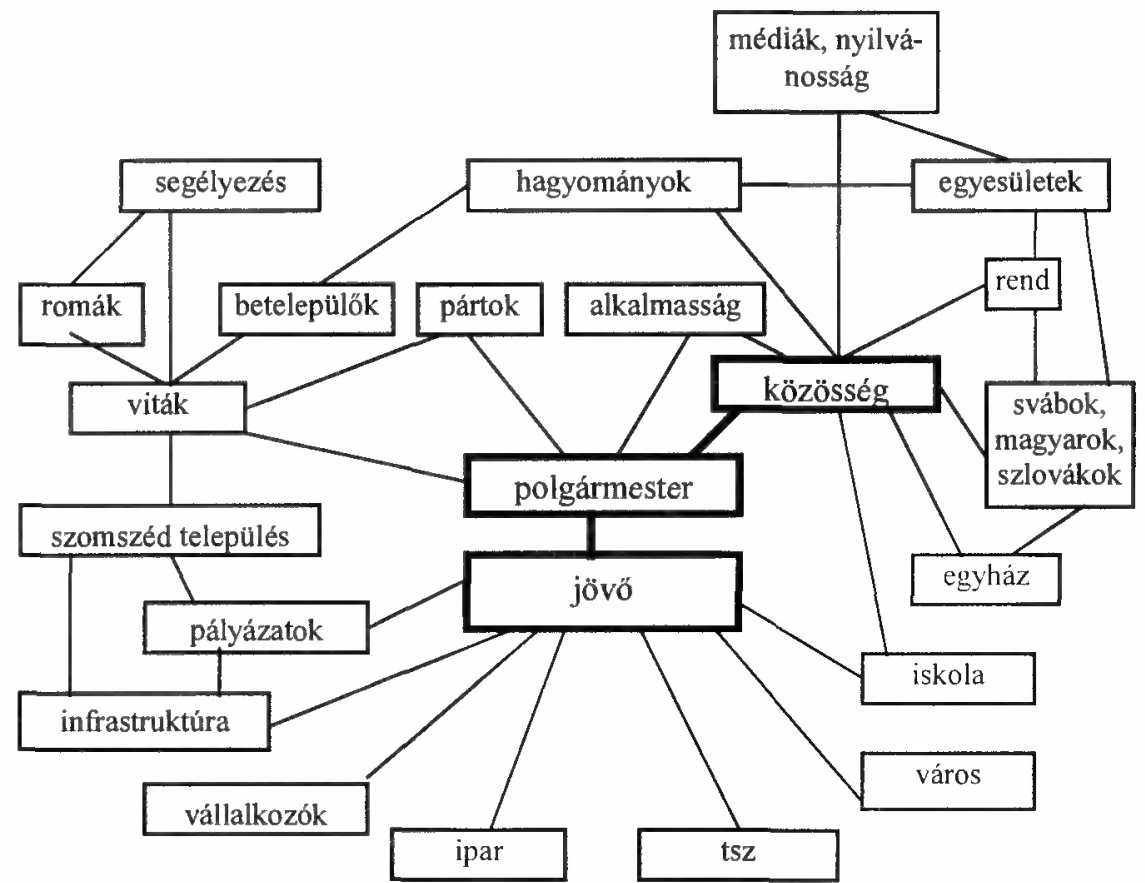

Forrás: interjúk.

A polgármesterek elbeszéléseit szövegekként értelmezve az egyes szövegek struktúrájának alapját a „közösség”, a ,jövő” és a „polgármester” egymáshoz kapcsolódása adja. A polgármester a közösség képviselője és megbizottja, aki az eltéró véleménnyel rendelkező helyi szereplök közös platformra hozatalára törekszik. De a polgármester a falusi jövő alakításának is kulcsszereplője. Viták, eltéró vélemények csak a pártok, a „törzsökösök" és a betelepülő́k, valamint a szomszéd települések között, illetve a segélyezésröl és a romákról folynak. A „viták” és a „közösség” között nincs közvetlen kapcsolat. A közösséghez szorosan kapcsolódik a nyilvánosság, az egyesületek, a rend, a hagyományok és az egyház fogalma. Amikor a kívánatosnak tartott jövőkép a polgármesteri beszéd témája, akkor az iskola, a város, a 
Borboly István - Csite András : A polgármester, a falu meg a közösség :

Hozzászólás a „független" polgármester vitához

Tér és Társadalom 13. évf. 1999/1-2. 109-128. p.

tsz, az ipar, a vállalkozók, az infrastruktúra és a pályázatok fordulnak elő az elbeszélésben.

A polgármesterek beszédének középpontjában álló kategóriák három érvelési stratégiába rendeződnek. Az első a polgármester pozíciójának diszkurzív meg- és újrakonstruálása, mely két elemböl tevődik össze: egyrészt abból, hogy a falut közösségként képviseli, azaz a partikuláris érdekekkel szemben az általános közjót követi munkájában, másrészt pedig kifelé, a falun kívưl a községet, mint egységes csoportot jeleníti meg. A másik stratégia a falu közösségiségének folyamatos létrehozására irányul, a harmadik pedig a falu városétól különbözö jövőképének kifejtését („,külvárosiasodás” projekt), illetve a politikai döntések és a „szebb” jövő közötti közvetlen kapcsolat felmutatását foglalja magába.

\section{A polgármester}

A polgármesterek igyekeznek a közösségi összetartás, az „érdekegyesítés”, és az egyéni törekvések közötti feszültséget feloldani, a számos konfliktushelyzetet hol a közösség, hol az egyén szemszögéből értelmezni, s egyfajta „döntőbíróként” fellépni. Sajátos paradoxona a polgármesterek szimbólumteremtö- és értelmező tevékenységének, hogy igyekezetulk a közösség mítoszának fenntartására egyben saját mozgáslehetöségüket csökkenti, a múlt jelentésadása tehetetlenségi erővel bír a jelenben. A „falu szeme” elött tevékenykedö polgármester nem tehet meg „mindent”, „, nem ülhet be az autójába a munkaidő leteltével, mint a Demszky”. A polgármesteri pozícióra pályázók egyik legfontosabb törekvése „alkalmasságuk” bizonyítása. Nem fogadhatjuk el azt a szakirodalomban gyakran elöforduló nézetet, hogy a polgármesteri pozícióra számos településen alig akad/t alkalmas ember, avagy csak egy, a választásokon sikerrel szerepelt volt alkalmas az önkormányzat vezetésére. Ez a vélemény figyelmen kívül hagyja, hogy egy-egy politizáló közösségben az alkalmasságról folyó viták is relevanciával bírnak: az alkalmasság/alkalmatlanság kérdése politikai viták tárgya. Noha e politizálás nem a politizálás bevett intézményeiben, a parlamentben és az országos sajtó hasábjain, hanem a helyi nyilvánosság különbözö fórumain folyik, témájában, az elhangzó érvekben az „országossal” nagy hasonlóságot mutat. Jelöltként is csak az indul el, aki sikerrel tud amellett érvelni, hogy személye megfelelö a "feladatok elvégzésére", aki viszont az elözetes, jelöltállítási kampányban alkalmasságát nem tudta bizonyítani, jelöltként sem lépett fel. Az alkalmasság a politikai (különősen a kampány-) viták egyik legfőbb kérdése. Az adott jelölt személyiségéről, vezetöi kvalitásairól, lojalitásáról folyó vitákkal, rivális vélemények, vélemény-csoportok ütközésével találkozhatunk.

A falun belüli konfliktusokat, a versenyt a polgármesterek igyekeznek csillapítani, érvelésükben a falut, mint funkcionális egészet jelenítik meg, melyben nincs helye rivalizálásnak. Ugyanakkor a települések közötti kapcsolatokat, mint konfliktusokkal telteket jellemezték. A megkérdezett polgármesterek a községet kifelé egységesként igyekeznek megjeleniteni, a falun belüli egység mellett pedig azzal érvelnek, hogy az szükséges a települések közötti versenyben való sikeres helytálláshoz. Ez a 
Borboly István - Csite András : A polgármester, a falu meg a közösség :

Hozzászólás a „független" polgármester vitához

Tér és Társadalom 13. évf. 1999/1-2. 109-128. $p$.

verseny nem csupán a fejlesztési eröforrásokért folyik, de a külföldi, illetve hazai befektetőkért, a falu lakosságának betelepülőkkel való fiatalításáért (a városi fiatalabb családokért), az elmúlt években kiépített infrastruktúra müködtetéséért, azaz „a falu jövőjéért". A falu jövőstratégiáját a polgármesterek több elemböl állónak tekintik. Az elöregedés és az „elcigányosodás” képezik elsősorban azokat a veszélyeket, melyek a jövőstratégia sikerét megakadályozhatják, így az oktatás, a szociális segélyezés, a közmunkák, a bünmegelözés és bünüldözés terén tapasztalt igyekezet a jővőt potenciálisan veszélyeztető emberek integrálására, illetve az ellenszegülök szegregálására, a települések közötti ,jövö-verseny" egyik elemének tekinthető.

$\mathrm{Az}$ interjúalanyok szerint az emberek érzékenyek községük sikereire és lemaradására, a polgármesterek csak akkor tudják pozíciójukat és tekintélyüket megőrizni, ha olyan eredményeket produkálnak, melyek elismerésre tartanak számot (legyen az iskola-felújítás, postahivatal létesítése, avagy a templom felújítása). Így a központi kormányzat azon törekvése, hogy a települések között intézményfenntartó társulásokat hozzanak létre, nem egyezik a falusi politizálás elveivel: a falu önállósága, a polgármester és a település sikere épp a minél szélesebb saját intézményrendszer kiépítésében és fenntartásában ölt testet.

\section{A falu, mint közösség}

A falu közösségkénti meg- és újraalkotásában a közös falusi múlt megkonstruálása az egyik legfontosabb momentum. Kulönösen a falusi ünnepek múltra vonatkoztatásában, a történeti emlékhelyeken tartott közös megemlékezésekben, a falu múltját feltáró reprezentatív kiadványokban ơlt testet ez a törekvés. A kilencvenes évek első felében a tanácsrendszer megszünését követően „visszaszerzett” települési önállóság a közösségi helyek átszabásában is jelentkezett. A templom „visszanyerte régi szerepét", mint a falu egyik legföbb szimbolikus jelentéssel bíró tere, de a temetők rendbetétele, millecentenáriumi emlékhelyek létrehozása, az első és második világháborús falubéli áldozatok emlékoszlopának felújitása is a közös múlt megkonstruálásának eleme.

A falusi politizálás másik sajátossága, hogy úgy tartja fenn, termeli újjá a „faluközösség" mítoszát, hogy mindeközben azt át is dolgozza, az új keletú jelenségeket (pl. csatornázás, útépítés stb.) a helyi mítoszra vonatkoztatja, az újabb történéseknek a meglévő értelmezési mintázatok segítségével ad jelentést. Így egyszerre járul hozzá az elképzelt stabilitás és a fejlódés egységének fenntartásához.

\section{A falusi jövõ sajátszerüsége}

A polgármesteri érvelés visszatérő eleme volt a város és a falu, az adott község társadalomszervezỏdésének falusi jellegére való rámutatás. A falusi politizálás sajátszerüségét a polgármesterek nagyrészt a falu és a város között húzott választóvonal segítségével támasztották alá. A falusi politizálás érvelésükben úgy jelent meg, mint amelyben a szereplők a ,csapatmunkát” részesítik előnyben a konfliktussal szemben. A nagypolitika részben ismeretlen, idegen a „falutól”: fent Budapesten, az országgyủlésben, valamelyik hivatalban folyik, áttekinthetetlen és befolyá- 
Borboly István - Csite András : A polgármester, a falu meg a közösség :

Hozzászólás a "független" polgármester vitához

Tér és Társadalom 13. évf. 1999/1-2. 109-128. p.

solhatatlan. De a város, Budapest nemcsak a nagypolitika és a helyi politika között húzott választóvonal másik oldalán, hanem a falu fejlỏdésének lehetséges irányaiban is megjelenik. Ebben a kontextusban a város már nem idegen, hanem inkább vonzó, fejlettebb életlehetőségeket kínáló településforma. A helyi infrastrukturális beruházások elfogadtatásában, a telepúlés arculatának formálása során a megoldások mikéntjének megfogalmazásában a városi minták kiemelt szereppel bírnak.

A „fiatalok", a betelepülők kérdésköre kapcsán is tetten érhetö a város-falu különbségtétel. Mig a polgármesteri érvelésben a falu szocialista időszakbeli múltja, mint az „elöregedés” korszaka szerepel, addig a kilencvenes évek - jelentős kormányzati támogatással alátámasztva - a „fiatalokért való versenyként” jelennek meg. Ebben az összefüggésben a város és a falu egymással versenyben állóként értelmezödnek. A város, a centrum így mind idegenként, mind mintaként, mind pedig versenytársként is elöfordul a polgármesterek beszédében.

\section{Összefoglalás}

A falusi politizálás problémakörét a polgármesterek beszédének kulcsfogalmai segítségével közelítettuk meg. Arra összpontositottunk, hogy a falusi politizálásban nagy szereppel bíró önkormányzati vezetők jelentésadási, értelmezési stratégiáit, a tárgyalt témákat és a szereplöket feltárjuk. Az érvelési stratégiák (a falu közösségkénti reprezentációja, a polgármester konszenzusteremtő szerepe stb.) feltehetően történeti állandosággal bírnak, s ez az állandóság azt is jelenti, hogy a helyi politizálásban vezető szerepre törekvő emberek értelmezési tevékenysége, cselekedetei nem állhatnak szöges ellentétben e történetiséggel bíró mintázatokkal.

A polgármesteri beszéd kulcselemeinek bemutatása után a „függetlenség” problémája új összefüggésbe helyezhetö. A „függetlenség” a polgármesteri interpretációban a pártoktól és a pártok dominálta „nagypolitikától” való fưggetlenséget jelent. Ebben az elhatárolódásban összesủrüsödik a falunak a városétól, s legföképpen a fővárosétól eltérő társadalomszerveződésének feltételezése, valamint a polgármester és az „országos” politikus közötti különbségtétel (az elöbbi javára). Ugyanakkor azt is láttuk, hogy a várostól való kủlönállás, a pártoktól való távolságtartás, illetve a polgármester konszenzusteremtő szerepe a megkérdezettek érvelésében kontextus-fugggó: számos helyen a város, mint a kívánatos jövő attribútumaival bíró jelenik meg; a pártok nyújtotta lehetőségeket alkalmanként kiaknázzák (pl. kapcsolatok mobilizálása a választási kampányban), illetve egyes helyi szereplöcsoportok törekvéseinek partikulárissá nyilvánitásáért viták folynak.

A polgármesterek beszédének elemzése azt mutatja, hogy a falusi vezetők a politikai képviselők Bourdieu által feltárt nyelvi-diszkurzív stratégiáit alkalmazzák. Létrehozzák a képviseltek egynemủ csoportját, önmagukat a csoport képviselőiként jelenítik meg, s énjük felolvad a csoportközösség „mi”-jében. Az „országos/párt” politikusoktól való különbözőségưk abban áll, hogy az általuk (is) létrehozott és képviselt csoport nem egy „nagyobb” társadalmi egységet (réteget, osztályt, nemzetet, polgárokat stb.) jelent, hanem egy telepúléstípus, a falu feltételezett meglété- 
Borboly István - Csite András : A polgármester, a falu meg a közösség : Hozzászólás a "független" polgármester vitához

Tér és Társadalom 13. évf. 1999/1-2. 109-128. p.

hez kötődik. Annak eldöntése, hogy a független polgármesterek, avagy az országos pártpolitikusok politizálása tekinthetó-e társadalmilag hasznosabbnak, elöremutatóbbnak, nem szerepelt céljaink között. A politikusok e két csoportja politikai képviselö, s a versenyelvú demokráciák képviselőinek diszkurzív eszkőztárát alkalmazza.

\section{Jegyzet}

1 A tanulmány az OTKA F 020880 „A vidéki politikai elit osszetételének alakulása 1988-1994 között” c. kutatási program keretében készillt. A tanulmány elkészítéséhez nyújtott segítségéért köszơnettel tartozunk Boda Zsoltnak, Csigó Pétemek, Kiss Balázsnak, Kovách Imrének, Kovács Petrának, Laki Lászlonak, Szabó Mártonnak és Táll Évának.

\section{Irodalom}

Gergely A. (1992) Önkormányzat, polgári jog, helyi ơnszervezödés. - Juss. 1-2. 110-139. o.

Bocz J. (1995) Önkormányzati képviselők, polgármesterek. - Társadalom-statisztikai füzetek. 13. Budapest, $\mathrm{KSH}$.

Bocz J. (1996) Az önkormányzatok döntéshozói, 1994. Budapest, KSH.

Bourdieu, P. (1985) Az identitás és a reprezentáció: A régió fogalmának kritikai elemzéséhez. - Szociológiai Figyelö. 1, 7-22. 0.

Bourdieu, P. (1986) Distinction. Social Critique of the Judgement of Taste. London, Routledge.

Bourdieu, P. (1991) Language and symbolic power. Cambridge, Polity Press.

Böhm A. (1990) Az ơnkormányzat esélyei. - Társadalmi Szemle. 7. 49-55. o.

Böhm A. (1994) „Nagypolitika” és lokalitás - esszé a helyi politika esélyeiröl. Törésvonalak és értékválasztások. - Balogh I. (szerk.), Budapest, MTA PTI. 469-480. o.

Bơhm A. (1996) A helyi társadalom. Csokonai Vitéz Mihály Tanítóképző Föiskola Társadalomtudományi és Kozmüvelödési Tanszéke Kaposvár

Bőhm A.-Szz̋gyi L.--Spirulisz I.-Táll É. (1995) Túl az eufórián - Polgármesterek 1992. Polgármesterek túl az eufórión. - Táll É. (szerk.), Budapest, MTA PTI. 7-69. o.

Bőhm A.-Táll É. (1993) Demokrácia - Ónkormányzat - Piacgazdaság (Nemzetközi összehasonlító vizsgálat az új demokráciák helyi vezetöinek értékeiröl és a helyi hatalomról), - Társadalomkutatás. 4. 132-141. o.

Csigó P. (1997) A Bokros-csomag jelentősége a politikai diskurzusban. - Politikatudományi Szemle. 4. 27-56. 0.

Farkas J.-Vajda Á. (1991) Két választás Magyarországon 1990-ben. Budapest, KSH.

Gyenei M. (1992) „Mink cigányok-Kíremszipen-Haspártiak vagyunk” Választások Tiszabön. Önkormányzatt választások 1990. Politikai Szociológiai Körkép. - Bőhm A.-Szoboszlai Gy. (szerk.), Budapest, MTA PTI. 217-233. o.

Horváth M.T (1990) Pártok a fötéren. - Valóság. 11. 44-57. o.

Horváth M.T. (1993) Formák és határok (A helyi onkormányzatok politikai viszonyai). Új változatosság. Budapest, „Helyi demokrácia és újítások” Alapítvány.

Horváth M.T. (1996) Pártok a helyi önkormányzatokban. Budapest, Magyar Közigazgatási Intézet.

Kovács L.I. (1994) Voksok és mandátumok. Arányos-e az önkormányzati választási rendszer? - Társadalmi Szemle. 11.3-11. o.

Kukorelli I. (1991 a) Az önkormányzati választások jelzőtuzei. - Társadalmi Szemle. 1. 3-I0. o

Kukorelli I. (199lb) Pártok, civil társadalom a parlamenten kívul. Magyarország politikai évkönyve. Kurtán S.-Sándor P.-Vass L. (szerk.), Budapest, Aula. 187-195. o.

Kukorelli I. (I995) Önkormányzati választások 1994. Magyarország politikai évkönyve. - Kurtán S,Sándor P.-Vass L. (szerk.), Budapest, Aula. 99-110. o.

Kulcsár K. (1996) Politológiai megjegyzések az 1994. évi ơnkormányzati választásokról. Ónkormányzati választások 1994. Politikai Szociológiai Körkép.- Bőhm A.-Szoboszlai Gy. (szerk.), Budapest, MTA
PTI. 13-19. o.

Latour, B. (1987) Science in Action. Milton Keynes, Open University Press.

Németh Zs. (I99I) Helyhatósági választások Baranya megyében. - Comitatus. 9. 25-29. o.

Oláh M. (1996) Régi-új polgármesterek Veszprém megyében. Ónkormányzati választások 1994. Politikai Szociolỏgiai Körkép. - Böhm A.-Szoboszlai Gy. (szerk.), Budapest, MTA PTI. 195-209. o. 
Borboly István - Csite András : A polgármester, a falu meg a közösség : Hozzászólás a "független" polgármester vitához

Tér és Társadalom 13. évf. 1999/1-2. 109-128. p.

Pálné Kovács I. (1990) Helyi politika. Budapest, Akadémiai kiadó.

Pálné Kovács I. (I992) A helyi hatalom határai. Helyi társadalom, gazdaság, politika. Tanulmányok az önkormányzatokról. - Csefkó F. (szerk.), Budapest, Alapítvány a Magyarországi Önkormányzatokért. 60-72. 0 .

Pokol B. (1997) Szociológiaelmélet. Budapest, Felsöoktatăsi Koordinációs Iroda.

Szabó M. (1996) Vázlat a politika diszkurzív értelmezéséról. - Politikatudomámyi Szemle. 4. 101-132. o.

Szabó M. (1997a) Politikai tudáselméletek. Kézirat.

Szabó M. (szerk.) (1997b) Szövegvalóság. Írások a szimbolikus és diszkurziv politikáról. Budapest, Scientia Humana Társulás.

Szoboszlai Gy. (1992) Az 1990 évi önkormảnyzati választások politikuma. Változások a politikai erőviszonyokban. Önkormányzati választások 1990. Politikai Szociológiai Körkép. - Bóhm A.-Szoboszlai Gy. (szerk.), Budapest, MTA PTI. 11-32. o.

Szoboszlai Gy. (I996) Önkormányzati választások 1994. Önkormányzati választások 1990. Politikai Szociológiai Körkép. - Böhm A.-Szoboszlai Gy. (szerk.), Budapest, MTA PTI. 32-55. 0.

Szőgyi L. (1992) „Hát itt a demokrácia, ez kollobtt!” - A sértett Félfalu. Önkományzati választás Alsónémedin. Önkormányzati választások 1990. Politikai Szociológiai Körkép. - Bőhm A.-Szoboszlai Gy. (szerk.), Budapest, MTA PTI. 207-217. o.

Szógyi L. (1993) Polgármesterek pártpreferenciái. - Juss. 1-2. 161-167. o.

Szögyi L. (1994) Demokrácia-értelmezések a helyi vezetők kơrében. Törésvonalak és értékválasztások. Balogh I. (szerk.), Budapest, MTA PTI. 289-302. o.

Táll É. (1994) A helyi vezetők értékrendje. Nemzetkőzi vizsgálat a demokráciához és a piacgazdasághoz való viszonyukról. Törésvonalak és értékválasztások. - Balogh I. (szerk.), Budapest, MTA PTI. 273288. 0 .

Tóth L. (1991) A magyar falusi társadalom és a civil társadalom. - Juss. 3-4. 98-108. 0.

Velkey G. (1992) A települések önkormányzásáról. - Alfóldi Társadalom. Békéscsaba, Nagyalfơld Alapítvány. 140-157. 0.

Velkey G. (1994) Az onkormányzatok pártosodottsága. Egy empirikus vizsgálat tapasztalatai Békés megyében. - Társadalmi Szemle. 11.21-35. 0.

\section{THE MAYOR, THE VILLAGE AND THE COMMUNITY: CONTRIBUTION TO THE DEBATE ABOUT „INDEPENDENT" MAYOR}

\section{ISTVÁN BORBOLY - ANDRÁS CSITE}

In our study with 31 interview with mayors in villages we made an attempt to approach at frame, where politicising is appeared in village. The problems of politicising in village are approached with key concept of mayors' talking. The most important factor is ,,independence" which means independence of both parties and "high policy" dominated by parties. The assumption of the different social structure between village and city - and above all between village and the capital and the differentiation between the mayor and the "national" politic is emerged in this isolation. Mayors are applying the language discursive strategy of political representatives explored by Bourdieu: they establish the homogenous group of people being represented, they appear as a representative of the group and themselves are dissolved in the "we" of the group. The difference between them and ,national/party" politic is that the created group doesn't mean a ,larger" group (layer, class, nationality, citizen, etc.), but it connects to the existence of village, as a type of settlement. 